\title{
水文資料に起因する水資源計画の信頼度について \\ ON RELIABILITY OF WATER RESOURCES DESIGN \\ CAUSED BY UNCERTAINTIES OF HYDROLOGIC DATA
}

室 田 明*・江 藤 剛 治**.吉 岡 正 道***

By Akira Murota, Takeharu Eto and Masamichi Yoshioka

\section{1. 緒論}

水資源計画において，関倸するすべての要素を解析モ デルに組み込むことは不可能であり，まして計画の基礎 となる観測水文資料でさえ十分信頼することができない 以上，現状ではむしろ，各計画に不可避の誤差・不確実 性は積極的に肯定し, 各計画担当者は自らの計画の信頼 度を明確にしておくほうが合理的であろう。逆に信頼度 をある水準に規定すれば，水文資料の測定から計画の決 定にいたる全過程において精度上のバランスを保つこと ができる。このことによって解析モデルの精度の決定は もちろんのこと, 数多い水文解析手法のらちから各計画 に最適な手法の選択規準を定めることができるし, 雨量 計配置問題や流量測定法などの水文量測定法の選択決定 に必要な精度など, 水工計画上重要なさまざまの基準が 設定できるはずである。しかしながら，水資源計画の精 度・信頼度に関する統一的な説明を可能にするような研 究はいまのところほとんど皆無であるといって過言では ない。このような状況を背景として，1972 年 2 月にコ ロラド州立大学で開かれた第 2 回国際水文シンポジウ ム ${ }^{1)}$ や引引き続き行われたアリゾナ大学における国際シ

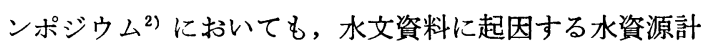
画の信頼度の問題がメーン・テーマの 1 つとして取り上 げられた。しかし，これらのシンポジウムにおいても， 一般的かつ実用的な解, あるいは手法が提示されたとは 言い難い。

これらの研究がこれほどまでに重要性を指摘されなが らいまだ十分な発展を見せていないのは，水資源計画の 全過程が非常に複雑なシステムを構成し, その統一的・ 理論的解析が困難であったことに由来すると考えられ

* 正会員 工博 大阪大学教授 工学部土木工学科

** 正会員 工修 近畿大学諈師 理工学部土木工学科

*** 学生会員 大阪大学大学院学生 工学研究科修士課程士木 工学専攻
る。

水資源計画の信頼度におよぼす水文量観測䛊差の影響 を評価するような場合を考えてみても, 水文量そのもの に㧍ける誤差の程度は直接的には問題とならず, 貯水池 そのほかによって次々に変換を受けた水文情報における 誤差が，たとえば最終的に渇水の強度を代表するような 量にどのような影響をおよぼすかが，真に我々の知りた い答であろう。この場合も，少なくとも貯水池システ ム, 渴水評価過程といったサブ・システムの特性が十分 把握されていなければならないことはいうまでもない。

このような見地より，本論文は大別して 2 つの部分か ら構成されている。第 1 の部分は渇水評価のプロセスの システム工学的定式化にあてられている。第 2 の部分は すでに発表した等価線形貯水池システムの理論と, 第 1 の部分における成果の適用により, 水文資料のさまざま の性質に起因する水資源計画の信頼度の減少について検 討したものである。解析の対象は, 正規分布をなす時系 列のごとき理想化された系列のみならず, 琵琶湖および 淀川支川木津川月が瀬測水所（高山ダム計画の基礎資 料）の 1918〜1965 年の間の実測資料も含んでいる。こ の部分は，筆者らの行ってきた水資源計画に拈けるシス テム工学的アプローチの一忘用例であるが，これにより この種の研究が実際の水資源計画における, 種々の基礎 的問題の解決のために非常に有効な手段となりうること が示される。

\section{2. 渴水評価の基準とその定式化}

\section{（1）流量の損失関数による評価}

わが国においては渴水や洪水のごとき自然災害に対し ては, 災害が起らないことによる利益を積極的に評価す ることは少なく, 発電用水などの場合を除いては, 計画 の評価を消極的に災害による損失量で行う場合が多い。 
洪水による損失は田畑の 冠水による被害, 住宅, 工 場, 公共土木構造物の被害や, 復旧費, 水害による住民 の精神的損失などの総和であり, 渴水による損失もまた さまざまの形で現われる。しかしながら，これらの個々 の損失を各ケースについて計算し，損失量を求めること は非常に煩雑であるばかりでなく, 解析方法・結果の一 般性を失うことにもなりかねない。よって既往の多くの 研究においては, 流量の関数としての損失関数を設定し 被害の程度を代表させている例が多いが，それらの中に はいろいろな意味で不都合と考えられる損失関数も多 い。筆者らはこの種の評価関数の具備すべき要件を次の ように考えている。

i ）いらまでむなくまず第 1 には，実際の 損失なり 利益とできるだけ直接的な関係にあること，

ii）一般性を有すること（多くの流域に打いてその 評価関数が仮定できること)，

iii）数学的取り扱いが容易であること。

以上 3 つの要件のすべてを十分に満す評価関数を見出 すことは非常に困難である。なぜなら,・たとえば最初の 要件と後者の 2 つの要件は一般に相反する要求となって いることが多い。よって各計画担当者あるいは研究者 は, 計画の特性・研究目的を明確にした上で, 上記 $3 つ$ の要件に照らしてもっとも妥当な評価関数を設定し，か つをた自らの用いた評価関数がどのような長所・短所を 持っているのかを常に照査しておく必要があろう。

\section{（2）渇水問題における損失関数の特性}

筆者らの知るかぎりでは，これまで渴水現象による被 害の生起パターンについて系統的に調べたものは少な い。しかし，たとえば都市用水のみの場合については藤 吉の論文 ${ }^{3)}$ に引用された建設省関東地方建設局が行った 上水道用水に対する東京都民の意識調査 ${ }^{4}$ などがある。 この調查は東京砂漠といわれた炤和 38,39 年の大渇水の 直後に行われており，また質問の適確さから筆者らはこ の調查結果を高く評価している。ここに引用するのは， 「異常渴水があって給水制限を行うとすれば水道利用者 はどこまでなら我慢できるか。」といら質問に対する回 答を整理したものであるが，すでに藤吉によって結論ゔ けられたことはここでは省略し，より定量的に検討して みる。アンケート結果は Fig. 1 の各点で表わされるが, 筆者らはこれに指数関数的減衰を仮定して，その定数の 持つ特性を調べてみた。これが破線で記されているが， 適合度は十分といえよう。この式は次のように表わされ る。

$$
L=A\left(1-e^{-t / B}\right)
$$

ここに,

$L:$ 我慢できないと答えた回答者の割合,

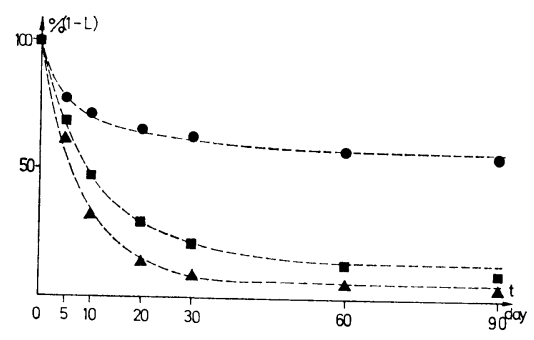

Fig. 1 Empirical Loss Function

Circles : $\left(X_{0}-X^{\prime}\right) / X_{0}=10 \%$,

Squares : $\left(X_{0}-X^{\prime}\right) / X_{0}=30 \%$,

Triangles: $\left(X_{0}-X^{\prime}\right) / X_{0}=50 \%$,

$X^{\prime}$ : Supplied Discharge, $X_{0}$ : Target Discharge

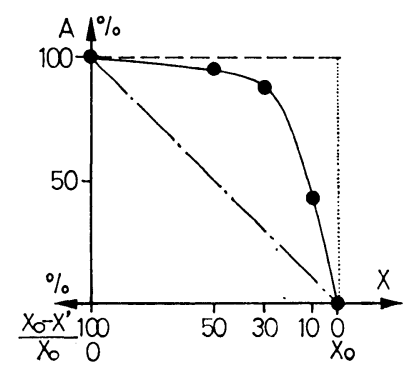

Fig. 2 Final Intensity of Drought

$A$ : 定数, ある強度の節水が無限時間続いたと考えた ときの損失の終極強度に対応するといえよう，

$B$ : 定数, 渴水評価におけるメモリーの長さを示して いる。

供給水量あるいは節水率を横軸にとって $A, B$ をプロ ットしたものが Fig. 2，3 である。これらの図より次 のようなことが言える。

i ） 終極強度に漸近する早さは節水率が大きいほど 早い ( $B$ が小さい)。この時定数 $B$ は最大 13 日程度で あり, 終極強度の $90 \%$ 程度の被害は最大約 1 力月以内 におこる。

ii） Fig. 2 において破線は渴水回数 $\left(X<X_{0}\right.$ なる ときはすべて等しい損失があると考えることと等価であ る）を損失関数とする場合，1点鎖線は不足水量を損失 関数とする場合の $A \sim X$ 関係に相当しているが, アンケート結果は両者の 中間的性質を示してい る。

よって以後の解析では 主として, 時間単位は月 程度と考え，流量評価の システムのメモリーは無 視して渴水回数・不足水 量がどのような性質を持 つかを調べよう。ただ本
Fig. 3 Length of Memory of Loss Function 
論文での解析が定量的な評価までは問題にしていないこ とも考虑すれば，以後の結果は $B$ と同程度，すなわち旬 流量程度を時間単位とする計画の策定に対しても十分適 用性があるものと考えられる。

\section{(3) 損失関数の定式化}

前項で述べたごとく時間単位は旬以上とし，nonmemory system による近似を許すものとする。これに より流量を input とし，損失量を output とする 1 種 のシステムを定式化する。流量時系列がどのような確率 分布を持ち，どのよらな従属性を持っていても，non linear system であれば現状のシステム工学の知識で解 くことは可能であるが，実用的な解を得ることはなかな か難かしい。ただ流量時系列が正規分布をなす場合につ いては, 古くは Davenport Root ${ }^{5)}$ の教科書の非線形解 析の項にも書かれてあるごとく，比較的簡単に解が求ま る。また流量系列が独立な系列をなす場合には確摔論的 取り扱いが容易となろう。この場合は確率分布に制限は 受けない。よってここでは次の 2 種類の解析法を用い た。

i ）流量系列が独立な系列をなす場合について，渴 水回数 (Filter 1 とする), 不足水量 (Filter 2 とする) の確率論的諸特性を導く,

ii）流量の確率分布が正規分布をなす場合について， 一例として損失が流量の指数関数として表わされる場合 (Filter 3 とする) の解を示す。同様の手法により，上 り一般的な non-memory system についても解くこと ができることは Davenport-Root の教科書などにも書か れてあるとおりである。

Filter 1，2，3 を Fig. 4 に示す。

i ）まず渴水回数，不足水量を評価関数とする場合 について述べる。ここでは流量系列を表わす変数として $X_{j}(j=1,2, \cdots, N)$ を用いる。また目標供給量は $X_{0}$ とし， $N$ 期間における $X_{j}<X_{0}$ なる期間の総数すなわ ち渴水回数を $n$ とし, $n$ および $S_{n}=\sum_{i=1}^{n}\left(X_{0}-X_{j}\right)$, (for $\left.X_{j}<X_{0}\right)$ なる総不足水量 $S_{n}$ の確率密度関数を求める (Fig. 5 参照)。

$X_{j}(j=1,2, \cdots, N)$ の時系列としては, $X_{j}$ は互いに 独立かつ定常時系列とする。またその確率分布関数を $F(X)$ とし， $X_{j}<X_{0}$ に対応する truncated distribution $F^{*}(X)$ を考える (Fig. 6 参照)。

$$
F^{*}(X) \begin{cases}=F(X) / q, & \left(X<X_{0}\right) \\ =0, & \left(X \geq X_{0}\right)\end{cases}
$$

ここに, $q=1-p=\int_{-\infty}^{X_{0}} \mathrm{~d} F(X)=F\left(X_{0}\right)$

このとき $n$ の確率密度関数はよく知られたように二項 分布となる。
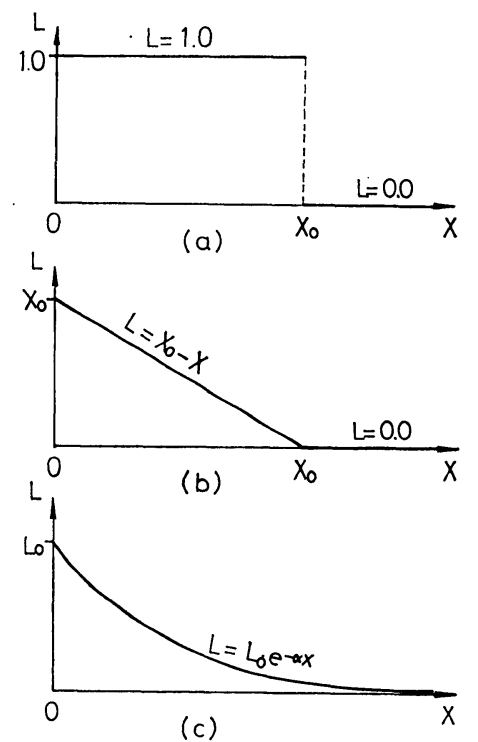

Fig. 4 Examples of Loss Functions

(a) : Filter 1, Number of Drought,

(b) : Filter 2, Sum of Deficit,

(c) : Filter 3, Continuous Loss Function

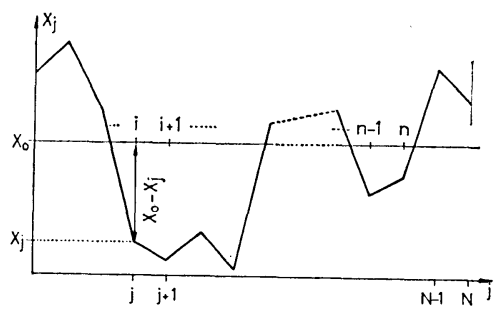

Fig. 5 Schematic Explanation of the Objective Sequence

$$
P_{r}(n=k)={ }_{N} C_{k} q^{k} p^{N-k}, \quad(k=0,1, \cdots, N)
$$

$F^{*}(X)$ に対応するあらたな 確率変数 $X_{j}^{*}$ を考え， そのキュムラント母関数，モーメント母関数をそれぞれ $K^{*}(v), M^{*}(v)$ とする。このとき，

$$
\begin{aligned}
M^{*}(v) & =E\left(e^{v X_{j}^{*}}\right)=\int_{-\infty}^{\infty} e^{v X} \mathrm{~d} F^{*}(X) \\
& =\frac{1}{q} \int_{-\infty}^{X_{0}} e^{v X} \mathrm{~d} F(X) \ldots \ldots \ldots \ldots \ldots
\end{aligned}
$$

$$
K^{*}(v)=\log M^{*}(v)=\sum_{r=1}^{\infty} \kappa_{r} * \cdot \frac{v^{r}}{r !}
$$

ここに, $\kappa_{r} *: X_{j}^{*}$ の $r$ 次のキュムラント（半不偏倸

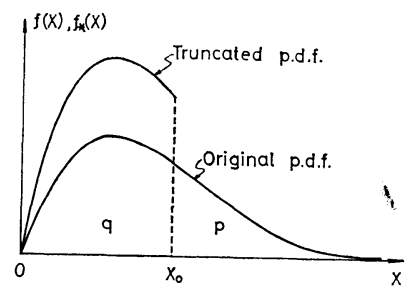

Fig. 6 Schematic Explanation of Truncated Distribution 
数), たとえば $\kappa_{1}^{*}=E\left(\mathrm{X}^{*}\right), \kappa_{2}{ }^{*}=V_{a r}\left(X^{*}\right), \cdots \cdots$

不足水量を $Y$ と書くと, $Y$ のモーメント母関数 $M_{Y}$ * (v) は,

$$
\begin{aligned}
& Y=X_{0}-X_{j}^{*} \\
& M_{Y} *(v)=E\left(e^{v Y}\right)=E\left(e^{v X_{0}-v X j^{*}}\right) \\
& =e^{v X_{0}} M^{*}(-v)=e^{v X_{0}} e^{K^{*}(-v)}
\end{aligned}
$$

$M(u, v), K(u, v)$ を $n$ と $S_{n}$ の結合積率母関数およ び結合キュムラント母関数とする。ここに $u$ ，vはそれ ぞれ $n, S_{n}$ に対するパラメーターである。このとき，※

$$
\begin{aligned}
& E(n)=\left.\frac{\partial K(u, v)}{\partial u}\right|_{\substack{u=0 \\
v=0}}=N q \\
& V_{a r}(n)=\left.\frac{\partial^{2} K(u, v)}{\partial u^{2}}\right|_{\substack{u=0 \\
v=0}}=N q(1-q) \\
& E\left(S_{n}\right)=\left.\frac{\partial K(\dot{u}, v)}{\partial v}\right|_{\substack{u=0 \\
v=0}}=N q\left(X_{0}-\kappa_{1}^{*}\right) \\
& V_{a r}\left(S_{n}\right)=\left.\frac{\partial^{2} K(u, v)}{\partial v^{2}}\right|_{\substack{u=0 \\
v=0}}=N q\left[p\left(X_{0}-\kappa_{1} *\right)^{2}+\kappa_{2} *\right] \\
& \rho\left(n, S_{n}\right)=\frac{\dot{C}_{o v}\left(n, S_{n}\right)}{\sqrt{V_{a r}(n) \cdot V_{a r}\left(S_{n}\right)}}=\left.\frac{\partial^{2} K(u, v)}{\partial u \cdot \partial v}\right|_{\substack{u=0 \\
v=0}} / \sqrt{V_{a r}(n) \cdot V_{a r}\left(S_{n}\right)}=\frac{1}{\sqrt{1+\frac{\kappa_{2}^{*}}{p\left(X_{0}-\kappa_{1}^{*}\right)^{2}}}}
\end{aligned}
$$

このようにして流星の確率密度関数, 月標放流量, サ ンプル・サイズがわかれば渴水期閵数 $n$, 不足水量 $S_{n}$ の確率分布がわかる。前述のごとく，この場合は確率分 布について適用上の制限は受けないが, 流量系列が独立 な系列をなすという大きな制約条件がつく。

ii）次に流量が正規分布老な寸場合についての解析 例を示す。簡単な例として Fig. 4 の Filter 3 の場合 を考える。損失を $Y$, 流量を $X$ とおくとき，

$$
Y=L_{0} e^{-\alpha X}
$$

$X$ の確率密度関数を $f(X), X_{1}$ と $X_{2}$ の結合確率密 度関数を $f_{12}\left(X_{1}, X_{2}\right)$, かつ $Y_{1}, Y_{2}$ を $X_{1}, X_{2}$ に対応 する出力 (損失) とする。添字 ‘ 1 ’, ‘2’ はそれぞれ時間 てだけ離れた量を意味するものとする。

$$
\begin{aligned}
& f_{Y}(Y)=f(X) \cdot\left|\frac{\partial X}{\partial Y}\right| \\
& \mu_{Y}=\int_{-\infty}^{\infty} Y(X) \cdot f(X) d X \\
& \sigma_{Y}^{2}=\int_{-\infty}^{\infty} Y^{2}(X) \cdot f(X) d X-\mu_{Y} \\
& R_{Y}(\tau)=\int_{-\infty}^{\infty} \int_{-\infty}^{\infty}\left(Y_{1}-\mu_{Y}\right)\left(Y_{2}-\mu_{Y}\right) \\
& \text { - } f_{12}\left(X_{1}, X_{2}\right) d X_{1} \cdot d X_{2}
\end{aligned}
$$

ここに $f_{Y}(Y), \mu_{Y}, \sigma_{Y}, R_{Y}(\tau)$ は $Y$ の確摔密度関 数, 平均, 標準偏差, 自己相関関数。

訃算を進めるために $X$ は $N\left(\mu_{X}, \sigma_{X}{ }^{2}\right)$ なる正規分布 に従うとし, かつ $X$ の自己相関関数を $\rho_{X}(\tau)$ とする。 このとき, ※※

$$
\begin{aligned}
& \text { ※※ } f_{Y}(Y)=\frac{1}{\sqrt{2 \pi \sigma_{X}}} \exp \left\{\frac{\left(X-\mu_{X}\right)^{2}}{2 \sigma_{X}{ }^{2}}\right\}\left|-\frac{1}{\alpha Y}\right| \\
& =\frac{1}{\sqrt{ } 2 \pi \sigma_{X} \alpha} \cdot \frac{1}{Y} \cdot \exp \left\{-\frac{\left(\frac{1}{\alpha} \log \frac{Y}{L_{0}}+\mu_{X}\right)^{2}}{2 \sigma_{X}{ }^{2}}\right\} \\
& \mu_{Y}=L_{0} \cdot \exp \left\{\frac{\alpha\left(\alpha \sigma_{X}{ }^{2}-2 \mu_{X}\right)}{2}\right\}
\end{aligned}
$$

同様にして，

$$
\begin{aligned}
& \sigma_{Y}{ }^{2}=L_{0}{ }^{2} \cdot \exp \left\{2 \alpha\left(\alpha \sigma_{X}{ }^{2}-\mu_{X}\right)\right\}-\mu_{Y^{2}}{ }^{2} \\
& R_{Y}(\tau)=L_{0}{ }^{2} \cdot \exp \left[\alpha \left\{\alpha \sigma_{X}{ }^{2}\left(1+\rho_{X}(\tau)\right)\right.\right. \\
& \left.\left.-2 \mu_{X}\right\}\right]-\mu_{Y}{ }^{2}
\end{aligned}
$$

以上の式より総損失は $T_{*} \cdot \mu_{Y}$ (ここに $T_{*}$ は観測時 間) で与えられ，そのときの分散 $V_{Y}\left(T_{*}\right)$ は,

$$
V_{Y}\left(T_{*}\right)=\frac{2}{T_{*}^{2}} \int_{0}^{T_{*}}\left(T_{*}-\tau\right) \cdot R_{Y}(\tau) d \tau
$$

より計算できる。以後の計算を進めるために, 式 (21) を $e$ に関して級数展開しておく。

$$
\begin{aligned}
R_{Y}(\tau) & =L_{0}^{2} \cdot e^{\alpha\left[\sigma_{X}{ }^{2} \alpha-\mu_{X}\right]} \\
& \cdot \sum_{i=0}^{\infty}\left\{\alpha^{2} \sigma_{X}{ }^{2} \rho_{X}(\tau)\right\}^{i} / i !-\mu_{Y}{ }^{2} \\
& =\mu_{Y}{ }^{2} \sum_{i=1}^{\infty}\left\{\lambda \rho_{X}(\tau)\right\}^{i} / i ! \ldots \ldots . .
\end{aligned}
$$

ここに, $\lambda=\alpha^{2} \sigma_{X}{ }^{2}$

さらに計算を進めるためには $\rho_{X}(\tau)$ に具体的な関数 を仮定する必要がある。たとえば,指数関数を考えれば,

$$
\rho_{X}(\tau)=e^{-\tau / k}
$$

$$
V_{Y}\left(T_{*}\right)=\frac{2}{T_{*}{ }^{2}} \int_{0}^{T_{*}}\left(T_{*}-\tau\right) \cdot \mu_{Y^{2}} \sum_{i=1}^{\infty} \frac{\lambda^{i}}{i !} e^{-i \tau / k} \cdot d \tau
$$




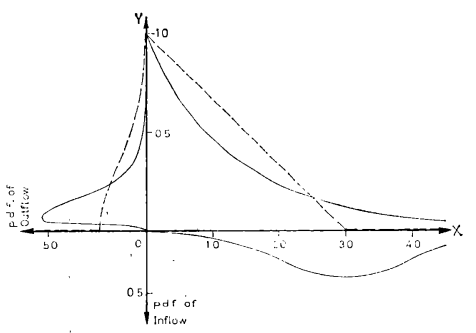

Fig. 7 Comparison of Loss Functions as Filters of Natural Discharge

$$
=\frac{2 \mu_{Y}^{2}}{T_{*}^{2}} \sum_{i=1}^{\infty} \frac{\lambda^{i} k^{2}}{i ! i^{2}} \cdot\left(\frac{i}{k} T_{*}+e^{-i T_{*} / k}-1\right)
$$

比較のための例として, Fig. 7 に $X \in N(3,1)$ なる 流量が次のような 2 種類の評価関数を通過したのちの出 力の確率密度関数を示す。

$$
\begin{aligned}
& Y= \begin{cases}3-X, & (X<3) \\
0, & (X \geqq 3)\end{cases} \\
& Y=3 \cdot e^{-(2 / 3) X} \quad \ldots \ldots \ldots
\end{aligned}
$$

式(26)は破線に, 式(27)は実線に対忘する。

\section{3. 水資源計画の信頼度}

\section{（1） 信頼度の規準}

本章では水資源計画の信頼度について論じている。そ の目的は, 前章あるいはすでに発表した貯水池システム に関する基礎的研究 ${ }^{6}$ などの，筆者らが行ってきた水資 源計画に対するシステム工学的アプローチの実際の計画 における適用性・有効性の検証, および計画の基礎とな る水文資料の性質に起因する水資源計画の信頼度の減少 について解析的かつ一般的な議論を行らことである。

このような議論を解析的に取り扱うためには, まず信 頼度といら莫然とした言葉の意味を，適当な関数をもっ て具体的に表現しておく必要がある。筆者らはこの規準 として次のようなものを選んだ。

前章に示したごとく, 計画の評価は対象期間における 総渴水回数 $n$, 不足水量 $S_{n}$ を用いる。 $n, S_{n}$ が安定し た值であればその期待値 $E(n), E\left(S_{n}\right)$ のみによって計 画は評価されよう。しかしながら，たとえば水文資料に 起因するもののみに限ってみても, 標本数の不足, 時閒 単位の取り方，水文観測誤差などの原因により $n, S_{n}$ に は各種の誤差 $\varepsilon_{n}, \varepsilon_{S_{n}}$ が含まれる。よってここでは計画 の信頼度評価の尺度として $\alpha=\varepsilon_{n} / E(n), \alpha=\varepsilon_{S_{n}} / E\left(S_{n}\right)$ を用いることにする。

\section{（2） 正規分布をなす入力における標本数の効果}

実際の水文資料を用いた解析を行う前に，正規分布を
なし，かつ一次マルコフ系列をなすとしてモデル化され た流入量系列を用いた解析によって, 筆者らのアプロー チの実際的な問題への適用性を検討しておく。

ここで取り扱われるのは, 単一の貯水池による水の貯 留・調節を含むモデル的な水資源開発システムにおける 計画の信頼度におよぼす水文資料数の影響である。

貯水池操作に括ける非線形性, 評価における従属性な どの効果は近似的な理論解とシミュレーション結果の比 較により補正することにして，まずは次のようないくつ かの粗い仮定をおく。

i ） 流入量の自己相関係数は $\rho$ でその時定数は $k=$ $\left(-\frac{1}{\log \rho}+\frac{1}{2}\right) \Delta t$ で与えられ6), 確率分布は $N\left(\mu, \sigma^{2}\right)$ なる正規分布に従らものとする。

ii）ダム操作方式は一定量放流方式とし，等価線形 貯留定数を $a$ とするとき ${ }^{6}$, 放流量の自己相関関数は近 似的に $R(\tau)=e^{-\tau /(a+k)}$ となり（すなわち時定数は $a+$ $k)$ ，その確率分布は $N\left(\mu, \frac{k}{a+k} \sigma^{2}\right)$ なる正規分布で近 似できるものとする。

iii）評価関数としては, 渴水回数・不足水量を用い るものとし, 前章の理論を適用するために放流量時系列 を時定数 $(a+k)$ ごとに区切って平均化したあらたな系 列を考え, これを独立な系列とみなす。このとき試長変 動曲線の理論より放流量系列の分散は,

$$
\begin{aligned}
& V_{a r} \mid T_{*}=a+k=\frac{2 \frac{k}{a+k} \sigma^{2}}{(a+k)^{2}} \int_{0}^{a+k}(a+k-\tau) \\
& \cdot e^{-\tau /(a+k)} d \tau=0.737 \frac{k}{a+k} \sigma^{2}
\end{aligned}
$$

となる。よってこの独立変数は $N\left(\mu, \frac{0.737 k}{a+k} \sigma^{2}\right)$ に従 うものとする。

iv）よってサンプル・サイズあるいは観測資料の長 さを $T_{*}$ とすれば，式 (9)〜(13) に扔いて，

$$
\begin{aligned}
& N=\frac{T_{*}}{a+k} \\
& F(X)=\frac{1}{\sqrt{2 \pi} \sigma \sqrt{\frac{0.737 k}{a+k}}} \\
& \cdot \int_{-\infty}^{X} \exp \left\{-\frac{(X-\mu)^{2}}{2 \cdot \frac{0.737}{a+k} \sigma^{2}}\right\} d X
\end{aligned}
$$

之抢くことにより渴水回数 $n$. 不足水量 $S_{n}$ の確摔分 布を規定する各次のモーメントが求まる。

v）計画の信頼度は, 渴水回数 - 不足水量の変動係 数, すなわち平均渴水回数 - 平均不足水量に対するその 標準偏差の比によって測られるものとする。式で書け ば, $\sqrt{V_{a r}(n) / E}(n)$ あるいは $\sqrt{V_{a r}\left(S_{n}\right)} / E\left(S_{n}\right)$ 。

ところで正規分布に対して計算してみると， 


$$
\begin{aligned}
& \left\{\sqrt{V_{a r}\left(S_{n}\right)} / E\left(S_{n}\right)\right\} /\left\{\sqrt{V_{a r}(n)} / E(n)\right\} \\
& \quad=\sqrt{1+\frac{\kappa_{2}{ }^{*}}{p\left(X_{0}-\kappa_{1}{ }^{*}\right)^{2}}}=\frac{1}{\rho\left(n, S_{n}\right)} \\
& \quad=1.3 \sim 1.5 \doteqdot 1.4 \cdots \cdots \ldots \ldots \ldots \ldots \ldots \ldots \ldots \ldots \ldots \ldots \ldots \ldots \ldots \ldots \ldots \ldots \ldots
\end{aligned}
$$

とほぼ一定であるから，この場合は渴水回数を用いて も不足水量を用いても本質的な差はない。ここでは不足 水量 $S_{n}$ のみについて考えることにする。

シミュレーション・ケース

は Table 1 に示すとおりで

Table 1 Simulation Cases

ある。またシミュレーション

手順は次のとおりである。

i) 各ケースについて 10000 個のデータを発生さ せ ${ }^{7)}$ ，まず平均不足水量を求 めた。

ii）次にそれらを 10 個ず つ 1000 組のデータに分け，

$\rho:$ Correlation Coefficient, $V, X_{0}$ : Capacity and Target Discharge of Reservoir, $T$ : Sample Number, $X$ : Inflow.

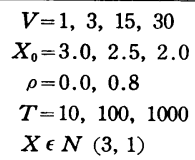

各 10 個ずつについて不足水量を求め，得られる 1000 個の不足水量についてその標準偏差を求めた。これはサ ンプル・サイズが 10 の場合の不足水量のばらつきを代 表しているはずである。

iii）同様に 100 個ずつ 100 組, 1000 個 ずつ 10 組の データについて標準偏差を求めた。

これらの值に貯水池操作の非線形性の補正を加えるた めに, $a / k$ と $E\left(S_{n}\right), \sqrt{V_{a r}\left(S_{n}\right)} / E\left(S_{n}\right)$ の関倸をプロ ットしてみた。シミュレーションによる正確な解を $[E$ $\left.\left(S_{n}\right)\right]_{\mathrm{sim}},\left[\sqrt{V_{a r}\left(S_{n}\right)} / E\left(S_{n}\right)\right]_{\mathrm{sim}}$, 筆者らの近似解を $[E$ $\left.\left(S_{n}\right)\right]_{\text {Theo, }}\left[\sqrt{V_{a r}\left(S_{n}\right) / E}\left(S_{n}\right) / E\left(S_{n}\right)\right]_{\text {Theo とすると, }}$ この補正により次のような関係式が得られた。

$$
\left[E\left(S_{n}\right)\right]_{\mathrm{sim}} \fallingdotseq 0.46(a / k)^{-1 / 3} \cdot\left[E\left(S_{n}\right)\right]_{\text {Theo }}
$$

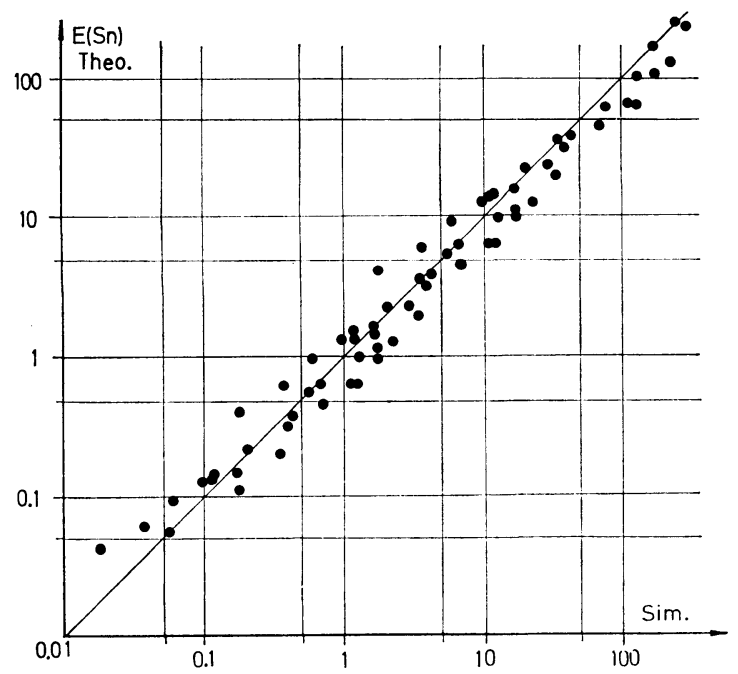

Fig. 8 Comparison of Theoretical Values with Simulated Values for $E\left(S_{n}\right)$

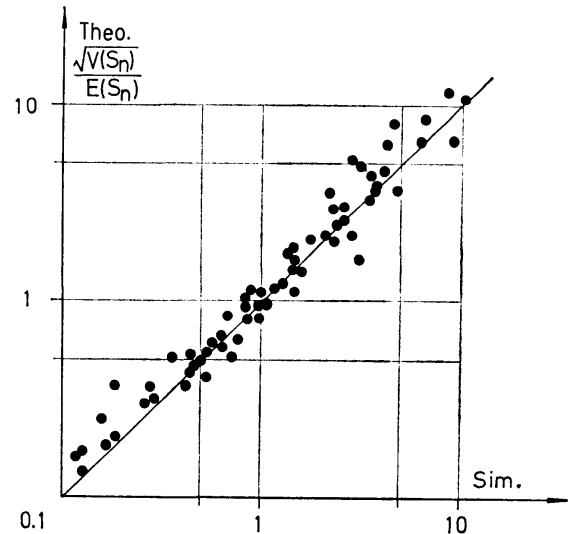

Fig. 9 Comparison of Therretical Values with Simulated Values for $\sqrt{V\left(S_{n}\right)} / E\left(S_{n}\right)$

$$
\begin{aligned}
& {\left[\sqrt{V_{a r}\left(S_{n}\right)} / E\left(S_{n}\right)\right]_{\mathrm{sim}} \fallingdotseq 2.4(a / k)^{1 / 4}} \\
& \text { - }\left[\sqrt{V_{a r}\left(S_{n}\right)} / E\left(S_{n}\right)\right]_{\text {Theo }}
\end{aligned}
$$

式 (32), 式 (33) の右辺より求めた理論解と, シミュ レーション值を比較したものが Fig. 8, 9 である。こ れらの図の適合度より，筆者らのアプローチが実用上か なりな適用性を持っていることがわかる。

\section{（3）現実の水資源計画の信頼度}

\section{a) 標本数との関係}

前節において求められた式 (32), 式 (33) を琵琶湖, 木津川高山ダムの計画に適用する。ケースは次のとおり である。

琵琶湖に対しては, 貯水池容量 $V=134.0,401.0$, $534.0,801.0 \times 30\left(\mathrm{~m}^{3} / \mathrm{sec}\right) \mathrm{day}$, 木津川に対しては $V=$ $8.7,45.0,95.0,190 \times 30\left(\mathrm{~m}^{3} / \mathrm{sec}\right)$ day である。この值 は琵琶湖に対してはそれぞれ， $0.5 \mathrm{~m}, 1.5 \mathrm{~m}, 2.0 \mathrm{~m}$, $3.0 \mathrm{~m}$ 計画に相当し，木津川の場合は利用率 $40 \%, 60$

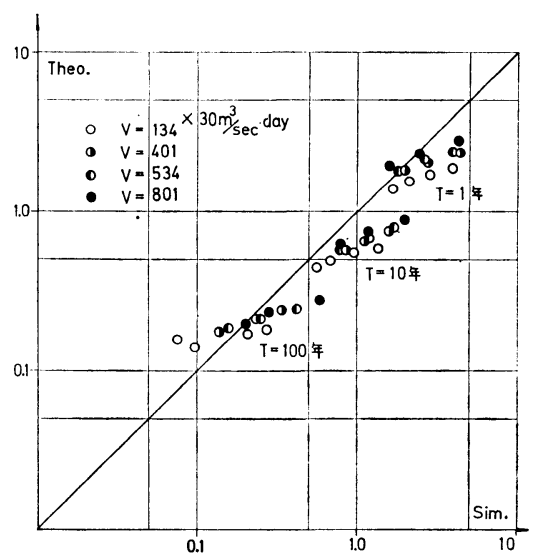

Fig. 10 Correlation between Theoretical Values and Simulated Values, $\sqrt{V_{a r}\left(S_{n}\right)} / E\left(S_{n}\right)$. An Example for Lake Biwa 
\%, 80\%, 90\% に対応している。目標放流量について は晹水がほとんど生起しない場合から 3 年に 1 力月程度 生起するような範囲について選んだ。次に実測流量資料 をもとに 1000 年分 (12000) 個の流量資料を模擬発生 した。以下の手順は前説と同じである。

シミュレーション結果と式(33)の比較の例を Fig. 10 に示す。この図よりわかるよらにサンプル・サイズの不 足による信頼度の減少の尺度としての変動率 $\sqrt{V_{a r}\left(S_{n}\right)}$ $\mid E\left(S_{n}\right)$ については, 式 (33) はある程度の適用性を有 しているといえよう。ただ係数 2.4 についてはあきらか に検討の余地がある。

式 (32) の適用性はあまりょくなかったが, 渴水回数, 不足水量の期待值については, 筆者らによるより高精度 の理論解があるので ${ }^{8}$ ，それを用いることができる。

式 (33) より,

$$
\begin{gathered}
\sqrt{ } \bar{V}_{a r}(n) / E(n) \sim \sqrt{V_{a r}\left(S_{n}\right)} / E\left(S_{n}\right) \\
\sim(a / k)^{1 / 4} \sqrt{(a+k) / T_{*}} \sqrt{p / q} \ldots \ldots . .
\end{gathered}
$$

ここに, $T_{*}$ ：観測時間あるいはサンプル・サイズ，で あるから，たとえば信頼度は放流量の時定数の平方根に 逆比例し, サンプル・サイズの平方根に比例する。

逆に計画の信頼度, あるいは許容誤差 $\alpha$ を規定してや れば，Fig. 10, 式 (33) よりそれに必要な資料数は求ま る。たとえば $\alpha=20 \%$ 程度とすれば, 琵琶湖の $1.5 \mathrm{~m}$ 計画では約 100 年以上, 木津川高山ダムの現状の操作方 式では約 50 年の資料が必要となる。信頼度を 2 倍に上 げて $\alpha=10 \%$ とするためには, さらに 4 倍の資料が必 要となる。

b）時間単位との関係

水資源計画の策定に際し, どの程度の時間単位を用い るのが最適かといら議論はかなり以前から繰り返されて きたにもかかわらず，いまだこれに関する一般的な理論 展開はもとより, 当面の計画に対する最適時間単位の選 定法も確立されてはいない。たとえば, 琵琶湖のごとき 大貯水池を有する流域に対して日単位で計画を立てるこ となどは, 直感的に考えてもナンセンスである。しかも それはデータ数の増減により計算機の記憶容量・計算時 間の短縮が計れるなどといった単純な問題ではない。た

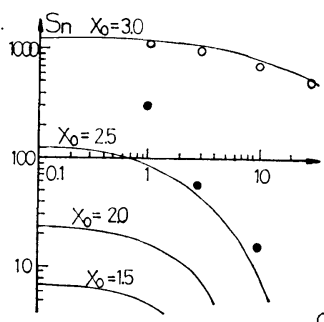

Fig. 11 Relation between $S_{n}$ and $\Delta t$

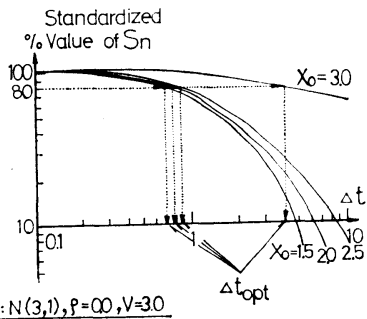

Fig. 12 Relation between $S_{n}$ and $\Delta t$

とえば，計画の基礎となる水文量の確率分布について も，日雨量では降水・無降水の 2 つの事象があり，その 取り扱いはきわめて面倒となるが，旬以上を単位とする 雨量ではその効果はほとんど無視できるし，時系列特性 についてもいろいろな流出成分の存在などによる流域の 非線形効果は，小さな時間単位を用いれば用いるほど卓 越してくる。これらがすべて時間単位の選び方に関係し てくるわけである。よってここでは水資源計画における 時間単位の決定法とそれに対応する計画の信頼度の推定 について述べる。

たとえば，時間単位を $N$ 倍にするといらことは，も との水文資料を $N$ 個ずつ加えた新たな水文量時系列を 用いて計画を策定することである。すなわち，N個 の 水文量の和の統計的諸特性がわかれば，その和に対する 渴水回数・不足水量を求めて, 原系列から求められるも のと比較することにより時間単位の影響が一般的に議論 できる。水文量の和の統計的特性については筆者らの文 献 9), 渴水回数・不足水量の期待值については同じく 6) に詳しい。

しかしながら，これらの式はやや煩雑なので，実用的 な見地からは放流量時系列の時定数の近似值 $(a+k)$ と 最適時間単位 $\left(\Delta t_{\mathrm{opt}}\right.$ と書くことにする) との関係が与 えられれば便利であろう。シミュレーションには次の 2 種類の資料を用いた。

i ） 正規分布・ガンマ分布について 10000 個のデー 夕を発生させたもの，

ii）琵琶湖・木津川月が瀬の 48 年分の半旬流量資 料。

以後の手順は次のと抢りである。

i ) まず最小時間単位の流量 (実測資料の場合は半 旬）を用いたシミュレーションにより $n, S_{n}$ を計算す る。

ii）次にそれらの流量を 2 つずつ加えて作った流量 資料（実測では旬流量）に対して同様の計算を行う。以 下順次時間単位を大きくして同様の計算を続ける。

iii）時間単位を横軸に, 不足水量 $S_{n}$ ・舅水回数 $n$ を綎軸に取って結果をプロットし, 外挿により時間単位

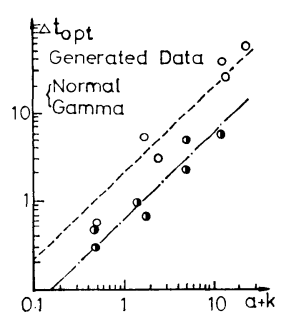

Fig. 13 Relation between $\Delta t_{\mathrm{opt}}$ and $(a+k)$

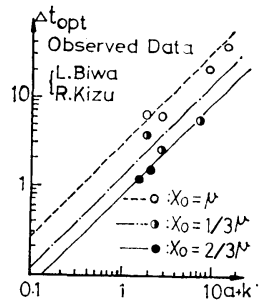

Fig. 14 Relation between $J t_{\mathrm{opt}}$ and $(a+k)$ 
$\Delta t=0$ のときの $n, S_{n}$ を求める。

iv) $\Delta t=0$ のときの值で除して規準化した不足水量 ・混水回数を計算し, $\Delta t=0$ のときの值に対するこれら の規準化量の誤差が $\pm \alpha \%$ (ここに $\alpha \%$ は許容誤差） となるときの時間単位を求め, これを最適時閒単位 $\Delta t_{\mathrm{opt}}$ とする。

以上の手順は Fig. 11，12 に示されている。

文献 6)，9）による理論解とシミュレーション結果を 比較したものの例が Fig. 11 であり，その規準化量が Fig. 12 である。また図中の丸が理論值である。これの 図より，筆者らの理論がかなりの精度を有していること がわかる。よって $\Delta t_{\mathrm{opt}}$ 決定に対する各パラメーター の影響などをより詳細に調べるには，この式が有効であ ることがわかる。

前述のごとく，より実用的な見地から $(a+k)$ と $\Delta t_{\mathrm{opt}}$ の関係を示したものが Fig. 13, 14 である。氷文量の 観測精度を考慮して，ここではかりに $\alpha=20 \%$ として いる。これより，実際の計画においてもっともよく使わ れる $X_{0} / \mu=1 / 3 \sim 2 / 3$ 付近に対して最適時間単位は,

$$
\Delta t_{\text {opt }} \fallingdotseq 0.7(a+k)
$$

で近似できることがわかる。すなわち， $\Delta t_{\mathrm{opt}}$ は放流量 の時定数に比例する。この值は琵琶湖で約 1 力月, 木津 川滈山ダムで 5 日〜10 日であるが， $\alpha=10 \%$ として許 容誤差を $1 / 2$ とするときは, $\Delta t_{\mathrm{opt}}$ の值もほぼ半分とな る。

\section{c）水文量観測誤差の影響}

水文量観測においては次の 2 種類の誤差の介人が-予測 される。

i ）正あるいは負の常に一定量の誤差，すなわち定 誤差,

ii） ガウス分布をなすような，いわゆる偶然誤差。 定誤差 $\Delta \mu$ が加わるときは自然流量すなわちダムへの 流入量の平均值 $\mu$ が, $\Delta \mu$ だけ変化して $(\mu+\Delta \mu)$ とな り，偶然誤差が介入するときは，その分散を $\Delta \sigma^{2}$ とすれ

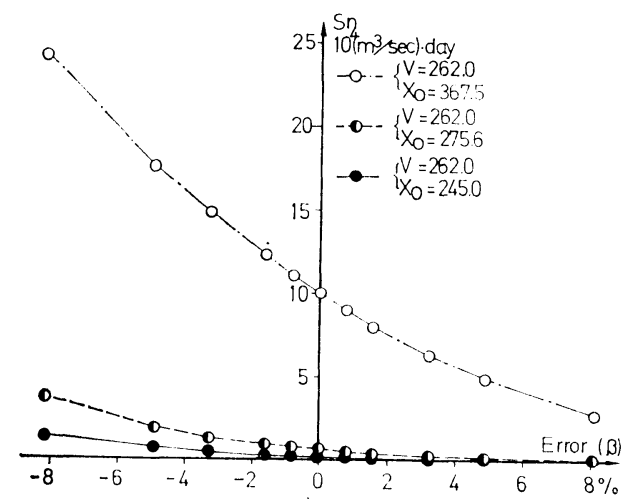

Fig. 15 Effect of Constant Error, Kizu River

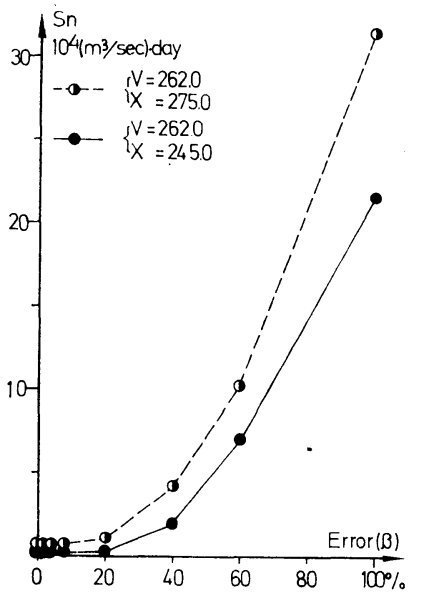

Fig. 16 Effect of Random Error, Kizu River

ば，流入量の分散が $\left(\sigma^{2}+\Delta \sigma^{2}\right)$ に変化すると考えられ る。

よって部画の信頼度への影響は次式で定義できるであ ろう。

$[\Delta \mu \cdot \partial E / \partial \mu] / E,\left[\Delta \sigma^{2} \cdot \partial E / \partial \sigma^{2}\right] / E \cdot$

ここに, $E$ は $E(n)$ あるいは $E\left(S_{n}\right)$ を意味してい る。 $\Delta \mu, \Delta \sigma$ が大きいときには，值接的に，

$\left[E_{\mu+\Delta \mu}-E\right] / E,\left[E v \overline{\sigma^{2}+\Delta \sigma^{2}}-E\right] / E$

を計算すればよい。ここに， $E_{\mu+\Delta \mu}, E v \overline{\sigma^{2}+\Delta \bar{\sigma}^{2}}$ は $E(n)$, $E\left(S_{n}\right)$ の計算において誤差を含まない流量資料の $\mu, \sigma$ のかわりに，それぞれ $\mu+\Delta \mu, \sqrt{\sigma^{2}+\Delta \sigma^{2}}$ を入れて $E(n)$ $E\left(S_{n}\right)$ を計算したものを意味する。

Fig. 15 に正あるいは負の定誤差を加えた場合の誤差 の大きさ $\beta$ と $S_{n}$ の関係, Fig. 16 に偶然誤差を加えた 場合の相対誤差の大きさ $\beta$ と， $S_{n}$ の関係を示すグラフ の例を示している。オーダー的に次のようなことがいえ る。ここに渴水回数 $n$, 不足水量 $S_{n}$ に打る誤差 $\alpha$ と 区別するために流入量における相対誤差は $\beta$ で表わして いる。

i ） 定誤差を加えたときは, $\beta= \pm 5 \%$ で $S_{n}$ は約 $1 / 2$ あるいは 2 倍となる。このとき $S_{n}$ における誤差の大き さは $\alpha \fallingdotseq \pm 100 \%$ となっている。 $\alpha$ を $\pm 20 \%$ 以下に押 えるためには $\beta$ は少なくとも $2 \%$ 以下に押えねばなら ない。

ii）偶然誤差を加えた場合は， $\beta=20 \%$ で $S_{n}$ は約 2 倍となり $\alpha=100 \%$ となる。 $\alpha<20 \%$ とするために は $\beta<10 \%$ 以下に押えねばならない。

iii） 比較的 $S_{n}$ が大きいときは筆者らの解がよくあ うからこの場合はこの式によって簡単に, 測定誤差に よる水資源計画の信頼度の評価ができる。

$\alpha<20 \%$ の条件のもとにも5少し具体的に説明する。 たとえば，流量観測において，年に何度も流量測定を行 
って水位〜流量曲線を作ったとすると，各測定值の，得 られた水位〜流量曲線のまわりでの許容できるばらつき の程度は, それらのばらつきの平均的な大きさ, すなわ ち標準偏差において $10 \%$ 程度であり，水位〜流量曲線 自身は，各測定点の真の中心を通る線から2\% 以上ズレ てはいけない。热た同様に流速測定装置が常に2\%以上 の定䛊差を含むことも午されない。

以上の条件は現在の水文観測における最禀度の測量技 術水準に対育しているであろう。垁は本節における $\alpha=$ $20 \%$ なる条件はこのような理由により定められたもの である。

\section{4. 結論と展望}

筆者らが行ってきた水凟源計画のシステム工学的研究 の, 実際の計画における適用性・有効性の検証を行うこ と，また計画の基礎となる水文資料による水資源計画の 信頼度の減少に関する統一的説明と宽用的成果を得るこ とを目的に研究を行い, 次のような成果を得た。

i ）計画評価の規準としての渴水の被害強度につい て検討を行い，旬〜月以上の時間単位による水資源計画 に対しては，ある計画期間に対する総渴水回数あるいは 総不足水量による計画評価がほぼ可能であることを指摘 した。

ii）独立な時系列，あるいは正規分布をなす時系列 に対して総晹水回数・総不足水量の確率分布を導いた。

iii）上記の成果およびすでに筆者らの提案した等侀 線形貯水池システムの理諭を用いて, 実際の竍画に打け る水文資料の時間亩位の取り方, 標本数, 測定誤差など が水資源計画自身の信頼度におよぼす影響についての理 論的考察と実用的な推算法走示した。

以上のごとくこれまで筆者らが行ってきた水資源計画 におけるシステム工学的アプローチが, 実際の水資源計 画においても非常に有効な手段となりうることが示され た。

本論文の成果が，より一般的な場合に刘して拡張でき るかどらかについては，筆者らは次のように考えてい る。これまでの議論は単一の貯水池, 比較的簡単な評価
関数に対して行われたものであるが，多少，評価関数が 変わっても, 寸でに得られた結果と比較して, 定性的に 見てそれほど異なる結果が得られるとは考えられない。 またより多くの貯水池からなる複雑な貯留・調節システ ムに対しては，各勋水池に対して等俩な線形貯水池を仅 定することにより，線形であるがゆえに比較的簡些に重 ね命せをすることが问能であり，淺論の搪張にもそれほ どの困難さは伴わないであろう。

謝辞：本研究を行うにあたり，熱心な助力をいただ いた大成建設 田中 剛氏，ならびに昭和 47 年度特別 研究として本研究の遂行に協力していただいた桘谷寿 夫・藤黒邦博両氏に心からの感謝の意を表します。また 本研究は昭和 47 年度文部省科学研究費「特定研究 : 水 資源の欺留調節機能に関する研究(代表者：室田明)」の 補助を受けて行った。記して謝意を表する次第である。

計算に用いた電子計算機は, 大阪大学大型電子計算機 センターの NEAC 2200-700, および京都大学大型電子 計算機センターの FACOM 230-60 である。

\section{参考 文 献}

1) Proc. of Second International Symposium in Hydrology, Fort Collins, Colorado, U.S.A., Sept., 1972.

2) Proc. of Simposium on Uncertainties in Hydrologic and Water Resources Systems, Arizona Univ., Arizona, U.S.A., Dec., 1972.

3）藤吉三郎 : 利水計画の安全度に関する二, 三の考察一利 根川水系を例として一，土木学会誌，Vol. 56, No. 11, pp. 23 29, 1971 年 11 月.

4) 建設省関東地方建設局：水道アンケート洞査㪕告書（勧 編), 炤和 45 年.

5) Davenport, W.B.Jr. and W.L. Root : An Introduction to the Theory of Random Signals and Noise,

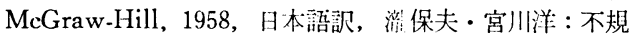
則信号と雑音の理諭, 好学社.

6) 室田 明・江藤剛治：利水を目的とした貯水池の貼留・ 調節機能に関する基礎的研究，上木学会諭文報售集，第 222 号, 1974 年 2 月.

7）室田 明・江藤剛治・解湯正剛：広域的な月水文量の解 析とそのシミュレーション, 上木学会諭文報皆 集, 第 203 号, 1972 年 7 月.

8) 6) に同じ.

9）室田 明・江藤剛治・田中 風：水文量の和汇関与る統 㨽的研究, 上木学会論文報告集, 第 223 号, 1974 年 3 月 予定。

（1973.6.27 • 受付） 